International Journal of Agricultural and Applied Sciences, June 2021, 2(1):118-122

https://www.agetds.com/ijaas

ISSN: 2582-8053

https://doi.org/10.52804/ijaas2021.2112

Research Article

OPEN ACCESS

\title{
Nutrient uptake by black gram (Vigna mungo L. Hepper) as influenced by phosphorus and boron fertilization in acid Inceptisol of Meghalaya
}

\author{
Muddana Sri Sai Charan Satya and Sanjay-Swami \\ School of Natural Resource Management, College of Post Graduate Studies in Agricultural Sciences, Central \\ Agricultural University, Umiam (Barapani) - 793103, Meghalaya, India \\ Corresponding author e-mail: csmuddana@ gmail.com
}

(Received: 27/12/2020; Revised: 29/05/2021; Accepted: 29/06/2021)

\begin{abstract}
Phosphorus and boron are required for growth and development of black gram, and play an important role in the uptake of other nutrients such as $\mathrm{N}$ and $\mathrm{K}$. The availability of $\mathrm{P}$ and $\mathrm{B}$ is less in acid soil because of fixation and leaching losses. Therefore, a field experiment was conducted to investigate the influence of $\mathrm{P}$ and $\mathrm{B}$ on $\mathrm{N}$ and $\mathrm{K}$ uptake in black gram with four levels of phosphorus $\left(0,25,50,75 \mathrm{~kg} \mathrm{ha}^{-1}\right)$ and four levels of boron $\left(0,0.5,1.0,1.5 \mathrm{~kg} \mathrm{ha}^{-1}\right)$ comprising of 16 treatments. The trail was laid out in split plot design and replicated three times. Phosphorus was used as main plot and boron as sub-plot. Significantly highest nitrogen concentration in black gram seed was observed at $\mathrm{P}_{75} \mathrm{~B}_{1.5}$ as $3.82 \%$, whereas in straw, it was observed at $\mathrm{P}_{75} \mathrm{~B}_{1}$ as $1.75 \%$. However, significant nitrogen uptake by seed and straw was recorded as 43.85 and $39.55 \mathrm{~kg} \mathrm{ha}^{-1}$ at $\mathrm{P}_{75} \mathrm{~B}_{1.5}$, respectively. Similarly, significantly highest potassium concentration in seed and straw was observed at $\mathrm{P}_{75} \mathrm{~B}_{1.5}$ as $1.13 \%$ and $1.64 \%$. Significant highest uptake of $\mathrm{K}$ by seed and straw was recorded at $\mathrm{P}_{75} \mathrm{~B}_{1.5}$ as $13.00 \mathrm{~kg} \mathrm{ha}^{-1}$ and $36.86 \mathrm{~kg} \mathrm{ha}^{-1}$, respectively. Therefore, $75 \mathrm{~kg}_{2} \mathrm{O}_{5}$ and $1.5 \mathrm{~kg}$ $\mathrm{B} \mathrm{ha}^{-1}$ is considered optimum for achieving higher nitrogen and potassium uptake by black gram in acid Inceptisol of Meghalaya.
\end{abstract}

Keywords: Acid soil, black gram, phosphorus, boron, nitrogen, potassium, uptake.

\section{INTRODUCTION}

Black gram (Vigna mungo L. Hepper) is one of the most important pulse crops grown in India. Being a legume crop, black gram not only builds soil fertility but also often plays a significant role for the successor crop in the nitrogen economy. It is essential to supply phosphorus, as it has beneficial effects on nodulation, nitrogen fixation, root production, growth and yield (Tamang and Sanjay-Swami, 2017). Phosphorus (P) is a key component of nucleic acids, phospholipids and ATPs and plays a role in a number of plant cellular processes such as cell division, energy storage and transition, respiration, photosynthesis and enzymatic activity (Tamang and Sanjay-Swami, 2021). Plants also require phosphorus for growth, sugar and starch utilization, photosynthesis, nucleus formation, and cell division (Atif et al., 2014). Boron is also an important micronutrient that plays a crucial role in multiple physiological and biochemical processes in plant bodies such as cell division and enlargement, cell wall formation, sugar translocation, metabolism of carbohydrates, metabolism of nitrogen and water relations (Oyinlola, 2007; Marschner, 2012, Satya and Sanjay-Swami, 2020). There is synergistic relationship to the rise in $\mathrm{P}$ uptake by plants under application of $\mathrm{B}$. (Huang et al., 2012), and also have significant synergetic effect in improving the production, yield and quality of plant species (Kaya et al., 2009; YuFan et al., 2012). Meghalaya soils are highly acidic, and phosphorus and boron are poor in supply. Low availability of phosphorus in these soils is due to fixation of $\mathrm{P}$ by $\mathrm{Fe}$ and $\mathrm{Al}$ oxides (Singh and Sanjay-Swami, 2020). Deficiency of boron in acidic soils of Meghalaya is due to coarse textured and leaching (Takkar, 1996, Satya and Sanjay-Swami, 2021). The low availability of $P$ and $B$ also influence the uptake of $\mathrm{N}$ and $\mathrm{K}$. The present study aims at investigating the influence of $\mathrm{P}$ and $\mathrm{B}$ on nitrogen and potassium uptake by black gram in acid Inceptisol of Meghalaya.

\section{MATERIALS AND METHODS}

The field experiment was conducted at College of Post Graduate Studies in Agricultural Sciences, Central Agricultural University, Umiam, Meghalaya with four levels of phosphorus $\left(0,25,50,75 \mathrm{~kg} \mathrm{ha}^{-1}\right)$ and four levels of boron $\left(0,0.5,1.0,1.5 \mathrm{~kg} \mathrm{ha}^{-1}\right)$ which comprises of 16 treatment combinations laid in split plot design with three replications. Phosphorus was used as main plot and boron as sub-plot. The meteorological observations during crop period were recorded with an average temperature of $23.0{ }^{\circ} \mathrm{C}$, total rainfall of 1625.5 $\mathrm{mm}$. The physico-chemical properties of the initial soil 
sample are: sandy clay loam in texture, $\mathrm{pH}$ (4.99), EC (0.42), organic carbon (1.32\%), available nitrogen (251.35 $\mathrm{kg} \mathrm{ha}^{-1}$ ), available phosphorus (13.68 $\mathrm{kg} \mathrm{ha}^{-1}$ ), available potassium (233.24 $\left.\mathrm{kg} \mathrm{ha}^{-1}\right)$, available boron (0.054 ppm). Plant samples were collected at the time of harvesting and nitrogen, potassium content in plant was estimated by using standard protocols.

\section{RESULTS AND DISCUSSION}

Nitrogen concentration and uptake

An increase in nitrogen concentration and uptake in seed and straw of black gram was observed with each increase in phosphorus and boron doses (Table 1, Figure 1 and 2). Nitrogen concentration in seed at control (3.26\%) and 75

Table 1. Nitrogen concentration in black gram (Vigna mungo L. Hepper) as influenced by phosphorus and boron fertilization in acid Inceptisol

\begin{tabular}{|c|c|c|c|c|c|c|c|c|c|c|}
\hline \multirow[b]{3}{*}{ Treatments } & \multicolumn{10}{|c|}{ Nitrogen concentration (\%) } \\
\hline & \multicolumn{5}{|c|}{ Seed } & \multicolumn{5}{|c|}{ Straw } \\
\hline & $\mathrm{B}_{0}$ & $\mathrm{~B}_{0.5}$ & $\mathrm{~B}_{1.0}$ & $\mathrm{~B}_{1.5}$ & Mean & $\mathrm{B}_{0}$ & $\mathrm{~B}_{0.5}$ & $\mathrm{~B}_{1.0}$ & $\mathrm{~B}_{1.5}$ & Mean \\
\hline $\mathrm{P}_{0}$ & 2.973 & 3.297 & 3.367 & 3.413 & 3.263 & 1.230 & 1.440 & 1.520 & 1.543 & 1.433 \\
\hline $\mathrm{P}_{25}$ & 3.150 & 3.380 & 3.460 & 3.547 & 3.384 & 1.303 & 1.470 & 1.610 & 1.623 & 1.502 \\
\hline $\mathrm{P}_{50}$ & 3.387 & 3.500 & 3.597 & 3.603 & 3.522 & 1.380 & 1.500 & 1.667 & 1.697 & 1.561 \\
\hline $\mathrm{P}_{75}$ & 3.537 & 3.623 & 3.717 & 3.823 & 3.675 & 1.413 & 1.713 & 1.753 & 1.760 & 1.660 \\
\hline Mean & 3.262 & 3.450 & 3.535 & 3.597 & 3.461 & 1.332 & 1.531 & 1.638 & 1.656 & 1.539 \\
\hline & $\mathrm{SE}(\mathrm{m}) \pm$ & $\sigma$ & C.D $(1$ & $0.05)$ & & $\mathrm{SE}(\mathrm{m})$ & & C.D ( & $.05)$ & \\
\hline $\mathrm{P}$ & 0.029 & 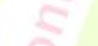 & 0.102 & & & 0.016 & & 0.057 & & \\
\hline B & 0.017 & 0 & 0.048 & & & 0.011 & & 0.033 & & \\
\hline $\mathrm{P}$ within $\mathrm{B}$ & 0.041 & $=$ & 0.132 & & & 0.025 & & 0.080 & & \\
\hline B within $\mathrm{P}$ & 0.033 & $E$ & 0.097 & & & 0.023 & & 0.066 & & \\
\hline
\end{tabular}

\section{Nitrogen uptake by seed}

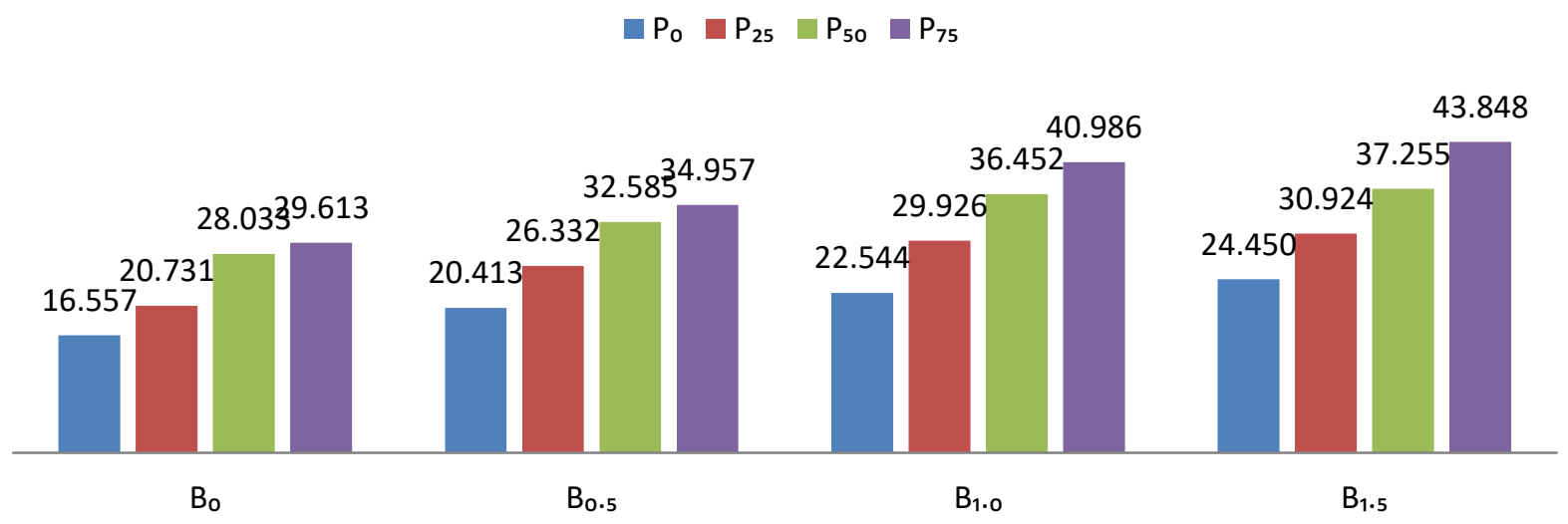

Figure 1. Nitrogen uptake $\left(\mathrm{kg} \mathrm{ha}^{-1}\right)$ in seed of black gram (Vigna mungo L. Hepper) as influenced by phosphorus and boron fertilization in acid Inceptisol

The interaction effect of phosphorus and boron on nitrogen concentration and uptake by seed and straw was found to be significant with lowest nitrogen concentration in seed was observed in control $\left(\mathrm{P}_{0} \mathrm{~B}_{0}\right)$ as 2.97 percent and significantly highest nitrogen concentration were observed at $\mathrm{P}_{75} \mathrm{~B}_{1.5}$ as 3.82 percent. The percent increase in $\mathrm{P}_{75} \mathrm{~B}_{1.5}$ over $\mathrm{P}_{0} \mathrm{~B}_{0}$ was 28.59 percent. The lowest nitrogen concentration in straw was observed in control at $\mathrm{P}_{0} \mathrm{~B}_{0}$ as 1.23 percent and significantly highest nitrogen concentration in straw was observed at $\mathrm{P}_{75} \mathrm{~B}_{1}$ as 1.75 percent. The per cent increase of $\mathrm{P}_{75} \mathrm{~B}_{1}$ over $\mathrm{P}_{0} \mathrm{~B}_{0}$ was 42.55 . Nitrogen uptake by seed was lowest in control i.e. $\mathrm{P}_{0} \mathrm{~B}_{0}\left(16.56 \mathrm{~kg} \mathrm{ha}^{-1}\right)$ whereas significantly highest nitrogen uptake was recorded as $43.85 \mathrm{~kg} \mathrm{ha}^{-1}$ at $\mathrm{P}_{75} \mathrm{~B}_{1.5}$. The per cent increase in $\mathrm{P}_{75} \mathrm{~B}_{1.5}$, 174.88. The lowest nitrogen uptake by straw was observed at control i.e. $\mathrm{P}_{0} \mathrm{~B}_{0}\left(17.41 \mathrm{~kg} \mathrm{ha}^{-1}\right)$ and significantly highest was observed at $\mathrm{P}_{75} \mathrm{~B}_{1.5}$ with 39.55 
$\mathrm{kg} \mathrm{ha}^{-1}$, with per cent increase in $\mathrm{P}_{75} \mathrm{~B}_{1.5}$ over control was 127.12. Laxmi et al. (2020) reported that boron application up to the level $1.0 \mathrm{~kg} \mathrm{ha}^{-1}$ was found to increase nutrient uptake by seed and straw and their total nutrient uptake in mungbean over control. Earlier workers also reported positive effect of boron on chlorophyll content which may be responsible for the increase in the nutrient content and uptake by plant with the higher growth characters. Yakuba et al. (2010) reported about the beneficial effect of boron in nitrogen uptake in legumes. Jyothi et al. (2018) reported that soil application of boron had significant effect on nitrogen and maximum $\mathrm{N}$ uptake was recorded with $1.5 \mathrm{~kg} \mathrm{~B} \mathrm{ha}^{-}$ ${ }^{1}$ as compared to $0 \mathrm{~kg} \mathrm{~B} \mathrm{ha}{ }^{-1}$.

\section{Nitrogen uptake by straw}

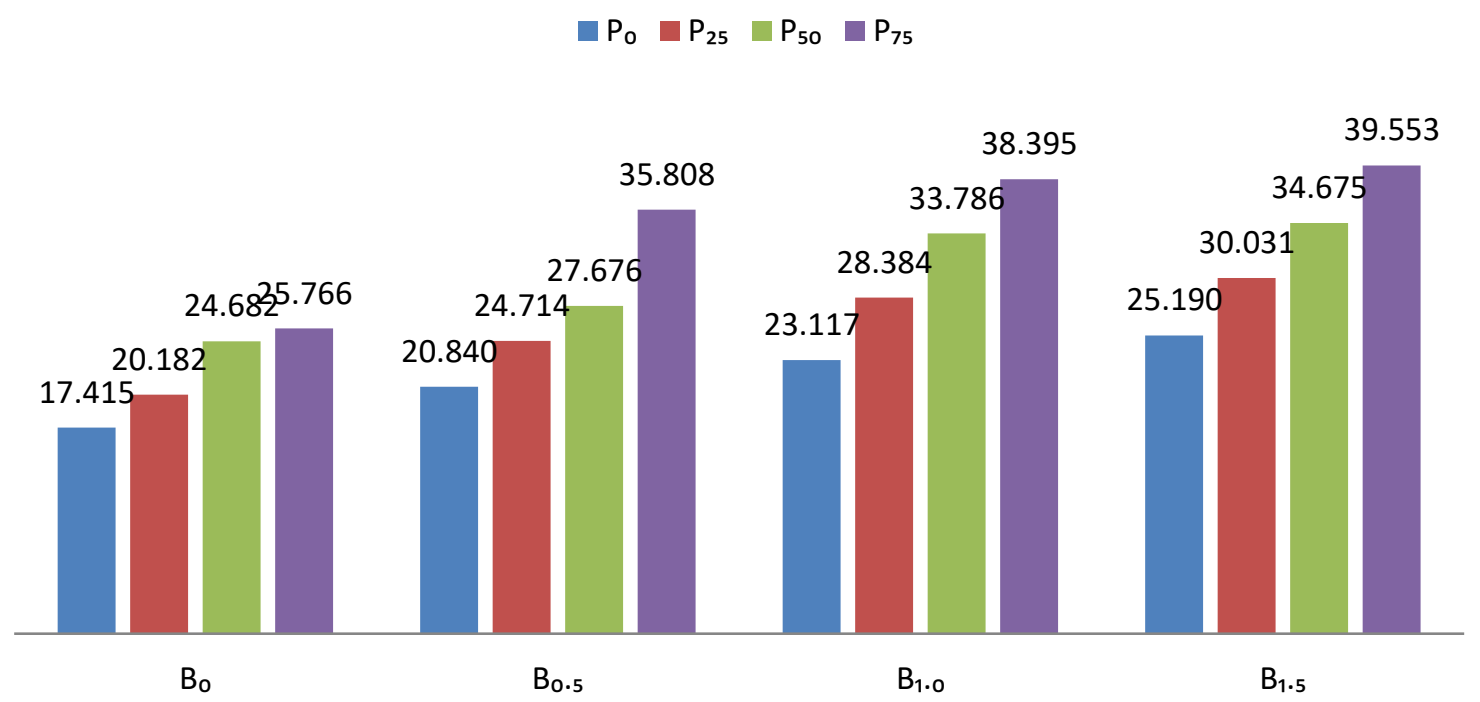

Figure 2. Nitrogen uptake $\left(\mathrm{kg} \mathrm{ha}^{-1}\right)$ in straw of black gram (Vigna mungo L. Hepper) as influenced by phosphorus and boron fertilization in acid Inceptisol

Table 2: Potassium concentration in black gram (Vigna mungo L. Hepper) as influenced by phosphorus and boron fertilization in acid Inceptisol

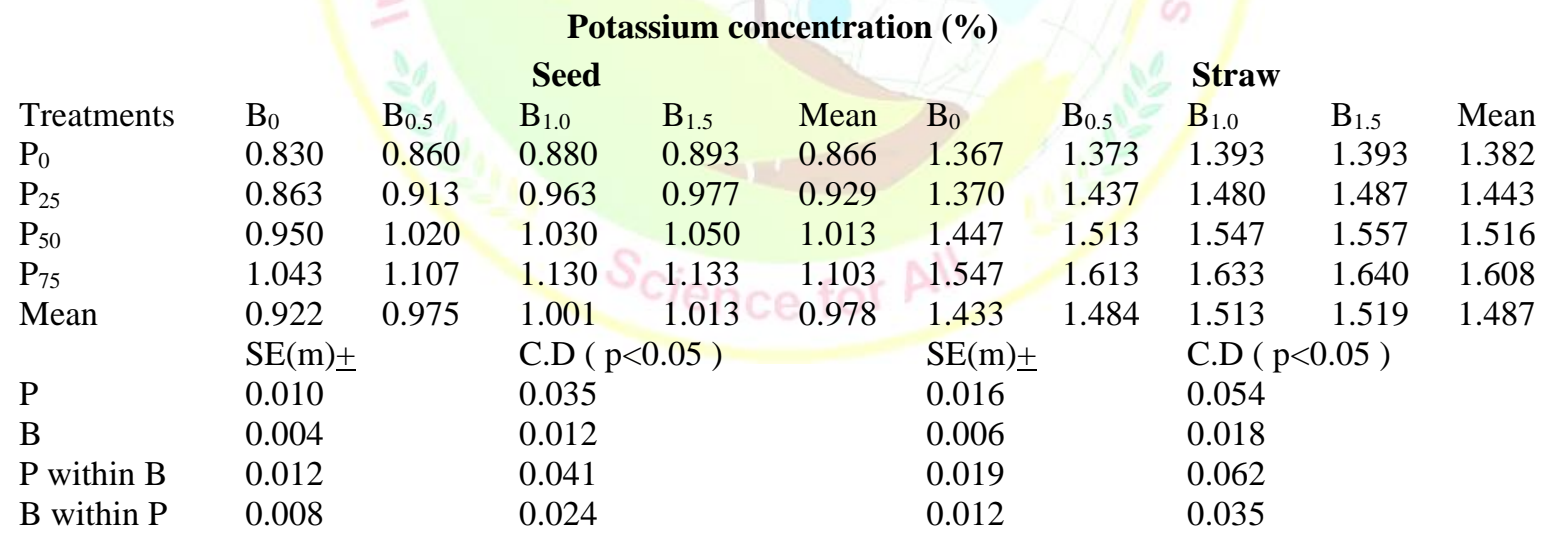

\section{Potassium concentration and uptake}

Potassium concentration and uptake in seed and straw of black gram was found to be increasing with increasing phosphorus and boron levels (Table 2, Figure 3 and 4). Highest potassium concentration and uptake was observed at $75 \mathrm{~kg} \mathrm{P}_{2} \mathrm{O}_{5} \mathrm{ha}^{-1}$ as 1.10 percent and $11.22 \mathrm{~kg}$ $\mathrm{ha}^{-1}$ in seed, and 1.61 percent and $33.67 \mathrm{~kg} \mathrm{ha}^{-1}$ in straw, and 1.01 percent and $9.69 \mathrm{~kg} \mathrm{ha}^{-1}$ in seed at $1.5 \mathrm{~kg} \mathrm{~B} \mathrm{ha}^{-}$ ${ }^{1}$ and 1.51 percent at $1.0 \mathrm{~kg} \mathrm{~B} \mathrm{ha}^{-1}, 29.73 \mathrm{~kg} \mathrm{ha}^{-1}$ at 1.5 $\mathrm{kg} \mathrm{B} \mathrm{ha}{ }^{-1}$ in straw. The lowest potassium concentration and uptake in seed and straw was observed at control
(0.87 and 0.92 percent); (1.38 and 1.43 percent) and (5.56 and $\left.6.72 \mathrm{~kg} \mathrm{ha}^{-1}\right)$; (20.79 and $23.65 \mathrm{~kg} \mathrm{ha}^{-1}$ ) at $\mathrm{P}$ and $\mathrm{B}$, respectively. The interaction effect of phosphorus and boron on potassium concentration and uptake by seed and straw was found to be significant. The lowest potassium concentration in seed and straw was observed in control at $\mathrm{P}_{0} \mathrm{~B}_{0}$ as 0.83 and 1.37 per cent and significantly highest potassium concentration was observed at $\mathrm{P}_{75} \mathrm{~B}_{1.5}$ with 1.13 and 1.64 per cent. The per cent increase in $\mathrm{P}_{75} \mathrm{~B}_{1.5}$, over $\mathrm{P}_{0} \mathrm{~B}_{0}$ was 36.54 and 20.00 
in seed and straw. Potassium uptake by seed was lowest in control i.e., $\mathrm{P}_{0} \mathrm{~B}_{0}\left(4.62 \mathrm{~kg} \mathrm{ha}^{-1}\right)$, whereas significantly highest uptake was recorded as $13.00 \mathrm{~kg} \mathrm{ha}^{-1}$ at $\mathrm{P}_{75} \mathrm{~B}_{1.5}$. The per cent increase in $\mathrm{P}_{75} \mathrm{~B}_{1.5}$ over control was 181.65 . The lowest potassium uptake by straw was observed at control i.e., $\mathrm{P}_{0} \mathrm{~B}_{0}\left(19.36 \mathrm{~kg} \mathrm{ha}^{-1}\right)$ and significantly highest was observed at $\mathrm{P}_{75} \mathrm{~B}_{1.5}$ as $36.86 \mathrm{~kg} \mathrm{ha}^{-1}$. The per cent increase in $\mathrm{P}_{75} \mathrm{~B}_{1.5}$ over control 120.14 respectively. Jyothi et al. (2018) reported that soil application of boron had significant effect on potassium uptake and maximum mean $\mathrm{K}$ uptake was recorded with $1.5 \mathrm{~kg} \mathrm{~B} \mathrm{ha}^{-1}$ as compared to $0 \mathrm{~kg} \mathrm{~B} \mathrm{ha}^{-1}$ (control).

\section{Potassium uptake by seed}

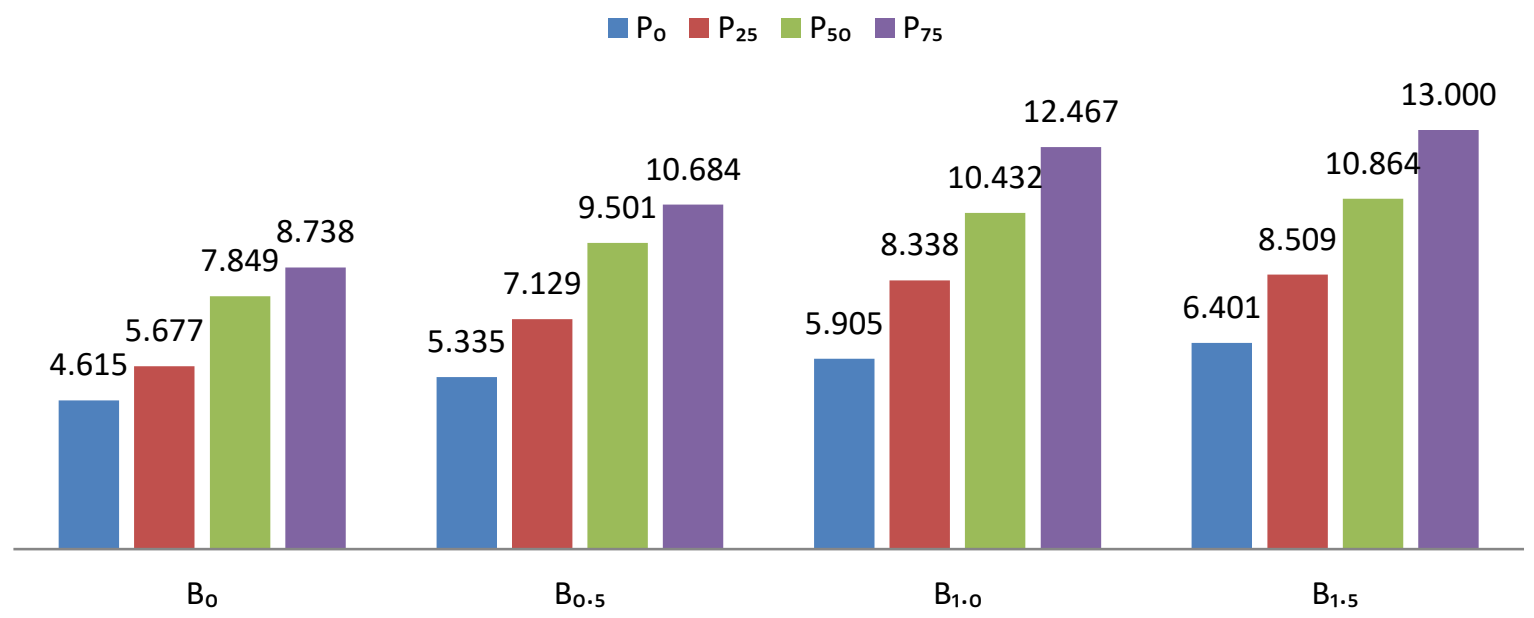

Figure 3. Potassium uptake ( $\mathrm{kg} \mathrm{ha}^{-1}$ ) in seed of black gram (Vigna mungo L. Hepper) as influenced by phosphorus and boron fertilization in acid Inceptisol

Potassium uptake by straw

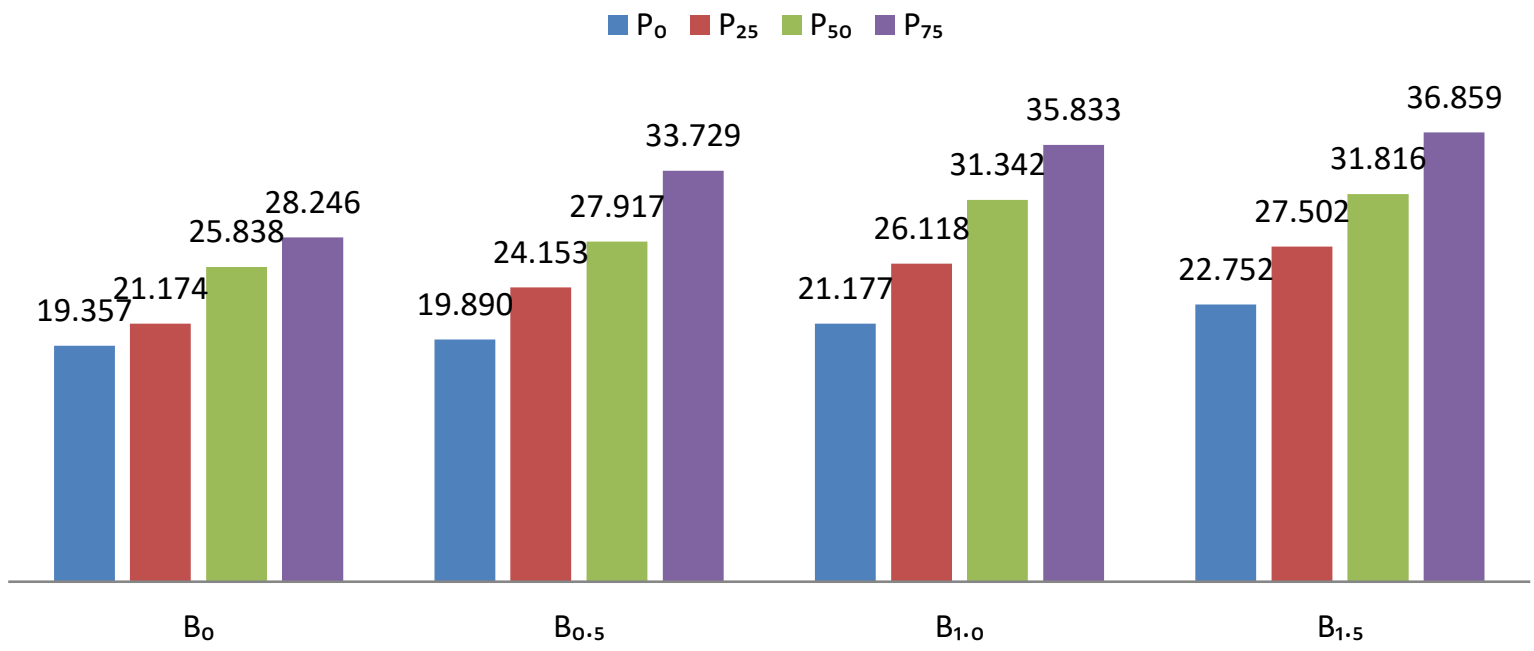

Figure 4. Potassium uptake $\left(\mathrm{kg} \mathrm{ha}^{-1}\right)$ in straw of black gram (Vigna mungo L. Hepper) as influenced by phosphorus and boron fertilization in acid Inceptisol

\section{CONCLUSION}

There was an increase in nitrogen and potassium content and uptake in seed and straw of black gram with each increasing dose of phosphorus and boron doses. Significantly highest nitrogen concentration in seed was observed at $\mathrm{P}_{75} \mathrm{~B}_{1.5}$ as 3.82 percent, in straw was observed at $\mathrm{P}_{75} \mathrm{~B}_{1}$ as 1.75 percent. Higher significant nitrogen uptake by seed was recorded as $43.85 \mathrm{~kg} \mathrm{ha}^{-1}$ at
$\mathrm{P}_{75} \mathrm{~B}_{1.5}$, by straw was observed at $\mathrm{P}_{75} \mathrm{~B}_{1.5}$ as $39.55 \mathrm{~kg} \mathrm{ha}^{-}$ 1. Significantly highest potassium concentration in seed and straw was observed at $\mathrm{P}_{75} \mathrm{~B}_{1.5}$ with 1.13 and 1.64 per cent. Potassium highest uptake by seed and straw was recorded as $13.00 \mathrm{~kg} \mathrm{ha}^{-1}, 36.86 \mathrm{~kg} \mathrm{ha}^{-1}$ at $\mathrm{P}_{75} \mathrm{~B}_{1.5}$. 


\section{REFERENCES}

Atif, M.J., Shaukat, S.A., Shah, S.Z.A., Choudhury, Y.A., and Shaukat, S.K. 2014. Effect of different levels of phosphorus on growth and productivity of pea (Pisum sativum L.) cultivars grown as offseason under Rawalakot, Azad Jammu and Kashmir conditions. J. Recent Adv. Agric., 2(6): 252-257.

Jyothi, P., Anjaiah, T., Murthy, I.Y.L.N., Naik, R., and Hussain, S.A. 2018. Seed yield and nutrient uptake of sunflower (Helianthus annuus L.) as influenced by different levels of boron and potassium in sandy loam soil. Int. J. Curr. Microbiol. \& App. Sci., 7(7): 3684-3692.

Kaya, C., Tuna, A.L., Dikilitas, M., Ashraf, M., Koskeroglu, S., and Guneri, M. 2009. Supplementary phosphorus can alleviate boron toxicity in tomato. Scientia Horti., 121: 284-288.

Laxmi, S., Meena, R., Meena, R.N., Patel, M.K., Paul, A., Dubey, A., and Meena, K. 2020. Effect of graded dose of sulfur and boron on yield and nutrient uptake by mungbean (Vigna radiata). Environ. \& Ecol., 38(5): 1-5.

Marschner, P. 2012. Marschner's Mineral Nutrition of Higher Plants. Academic Press, New York, USA. pp. 672.

Oyinlola, E.Y. 2007. Effect of boron fertilizer on yield and oil content of three sunflower cultivars in the Nigerian Savanna. J. Agron., 6(3): 421-426.

Satya, M.S.S.C. and Sanjay-Swami. 2020. Yield and yield attributes of black gram (Vigna mungo L. Hepper) as influenced by phosphorus and boron in acid Inceptisol. Inter. J. Agric. \& Appl. Sci., 1 (2): 73-78. ISSN: 2582-8053.

https://doi.org/10.52804/ijaas2020.1211
Satya, M.S.S.C. and Sanjay-Swami. 2021. Performance of black gram (Vigna mungo L. Hepper) under phosphorus and boron fertilization in acid Inceptisol of Meghalaya. J. Environ. Biol., 42 (2): 534-543. http://doi.org/10.22438/jeb/42/2(SI)/SI-281.

Singh, S. and Sanjay-Swami. 2020. Soil acidity and nutrient availability in Inceptisol of Meghalaya as influenced by Azolla incorporation. J. Nat. Res. Conser. \& Manag., 1(1): 07-14.

Takkar, P. N. 1996. Micronutrients research and sustainable crop production in India. J. $\mathrm{Pl}$. Physiol., 3: 237-239.

Tamang, B. and Sanjay-Swami. 2017. Effect of phosphorous and sulphur on nutrient uptake of blackgram (Vigna mungo L. Hepper) in acid Inceptisol. In: Natural Resource Management for Climate Smart Sustainable Agriculture, (eds.) Sanjay Arora, Sanjay-Swami and Suraj Bhan, Soil Conservation Society of India, New Delhi, pp. 298-309. ISBN: 978-81-909228-8-3.

Tamang, B. and Sanjay-Swami. 2021. Temporal availability of phosphorus and sulphur in acid Inceptisol as influenced by graded application of $\mathrm{P}$ and $\mathrm{S}$ under black gram (Vigna mungo $\mathrm{L}$. Hepper) production. Legume Res.: An Inter. J., 44 (5): 608-612. DOI: 10.18805/LR-4127.

Yakubu, H., Kwari, J.D., and Tekwa, J.A. 2010. Nodulation and $\mathrm{N}_{2}$ fixation by grain legumes as affected by boron fertilizer in Sudano-Sahelian zone of North Eastern Nigeria. AmericanEurasian J. Agric. Environ. Sci., 8 (5): 514-519.

YuFan, H., LongBin, H., XiaoLong, Y., and Hong, L. 2012. Effects of phosphorus and boron coupled deficiency on soybean growth, phosphorus, boron uptake and the genetic variations. J. South China Agric. Univ., 3(3): 129-134.

Citation: Satya, M.S.S.C and Sanjay-Swami 2021. Nutrient uptake by black gram (Vigna mungo L. Hepper) as influenced by phosphorus and boron fertilization in acid Inceptisol of Meghalaya. International Journal of Agricultural and Applied Sciences, 2(1): 118-122. https://doi.org/10.52804/ijaas2021.2112

Copyright: (C) Satya and Sanjay-Swami 2021. Creative Commons Attribution 4.0 International License. IJAAS allows unrestricted use, reproduction, and distribution of this article in any medium by providing adequate credit to the author(s) and the source of publication. 